Título do Trabalho:

\title{
TIPOLOGIA DE HABITAÇÃO DE INTERESSE SOCIAL SUSTENTÁVEL
}

Nome do Autor Principal:

Suellen Ferreira da Costa

Co-autores:

Paula Aparecida Santini de Almeida, Marina Mello Vasconcellos, Carlos Eduardo Soares de Sousa, Hiwersen Angelo Gnocchi Godoy,Victor Martins de Aguiar

Orientadores:

\section{Evandro Fiorin; Fernando Sérgio Okimoto}

Nome da Instituição

Faculdade de Ciências e Tecnlogia de Presidente Prudente-SP Curso de Arquitetura e Urbanismo Universidade Estadual Paulista "Júlio de Mesquista Filho"

E-mail de contato:

sucosta ara@hotmail.com; evandrofiorin@fct.unesp.br; okimotofs@fct.unesp.br

Palavras Chave:

Projeto; Tecnlogia; Sustentabilidade;

\section{INTRODUÇÃO}

O presente trabalho propõe a concepção projetual de uma nova tipologia de habitação de interesse social sustentável, porque prevê o re-uso de pneus, e que possa ser adaptada a três regiões geográficas do Estado São Paulo, a saber, Ribeirão Preto-SP, Atibaia-SP e Santos-SP. 


\section{OBJETIVO GERAL}

A proposta arquitetônica partiu da idéia de poder utilizar materiais geralmente descartados, tais como pneus, para a construção de uma tipologia habitacional que contemplasse uma disposição espacial com dois ou três dormitórios, sala, cozinha, banheiro e área de serviço. Assim, nesse projeto podem ser utilizados, tanto os "tijolos feitos com cimento e pedaços de pneu como agregado", ou blocos estruturais, também encontrados no mercado da construção civil, além de telhas ecológicas (nas tonalidades verde, azul e vinho) para vedação lateral e um sistema de brise-soleil para amenizar o calor, estruturados em uma trama feita de borracha de pneu.

\section{OBJETIVO ESPECÍFICO}

Desenvolver a possibilidade de adaptabilidade da proposta de habitação de interesse social sustentável em três regiões geográficas do Estado de São Paulo, que contassem com características climáticas diversas.

\section{METODOLOGIA}

Adotamos a possibilidade de re-uso dos pneus como agregado ao concreto na confecção da estrutura da habitação de interesse social e, também, isolante térmico na constituição de um brise-soleil em algumas das paredes da edificação. Testamos as possibilidades de implantação em algumas áreas de diferentes cidades do Estado de São Paulo.

\section{RESULTADOS}

Inicialmente definimos a borracha de pneu como material a ser trabalhado em âmbito construtivo e estético. Nesse sentido, optamos por utilizar os pedaços de borracha de pneu como um agregado que substitui a brita na confecção dos 
tijolos e também como vedação externa de algumas partes da construção de um projeto de habitação de interesse social. De outra forma, a borracha de pneu também serviu para configurar lâminas, que entrecruzadas, puderam se constituir como malha que formata um grande brise-soleil, ou seja, proteção para incisão direta de raios solares na edificação. Desta tipologia habitacional que projetamos, conjecturamos outras diversas, podendo estas ser dispostas em lote individual ou coletivo, geminadas ou separadas. Adotamos como cobertura, a laje plana impermeabilizada. Nessa idéia vemos uma maneira de maximizar o uso do terreno, prevendo a cobertura como um quintal suspenso. Sendo assim, na cidade de Ribeirão Preto-SP, essa laje plana poderia servir como uma área de lazer, em Atibaia-SP como solário e em Santos-SP como um grande pátio. É importante ressaltar que a proposta seguiu as normas e as determinações de metragem quadrada mínima, requeridas pela Companhia de Desenvolvimento Habitacional e Urbano do Estado de São Paulo.

\section{CONSIDERAÇÕES FINAIS}

Apresentamos neste trabalho as concepções arquitetônicas de uma tipologia de habitação de interesse social sustentável, que julgamos ser passível de construção e adaptação em diversas condições geográficas do Estado de São Paulo. Em se tratando de uma necessidade iminente da reutilização de pneus, concebemos uma proposta estético-construtiva como alternativa possível para o problema. Este trabalho é fruto de um concurso nacional de idéias e dispõe de um vasto material gráfico.

\section{REFERÊNCIAS}

HABITAÇÃO para Todos. São Paulo: Instituto de Arquitetos do Brasil, São Paulo, 2010. Disponível em:

$<$ http://www.iabsp.org.br/concurso regulamento.asp?|D=128 >. (Acesso: 18 jul. 2010). 